\title{
IN SEARCH FOR MEANING IN EVERY DAY LIFE: CAN THE VIRTUAL DOMINATE OVER REAL?
}

\author{
Yrd. Doç. Dr. DicLE YURDAKUL ${ }^{4}$ Doç. Dr. DENiz ATiK ${ }^{5}$
}

\begin{abstract}
Thanks to the rapidly developing internet technologies, people of the contemporary society have the freedom to experience many different forms of life at the same time. Millions of people around the world have become part of the virtual worlds such as Second Life and World of Warcraft which provide people with the power to be their own creators. These virtual worlds not only provide the individuals with the freedom to create themselves and their lives, but also with the opportunity to have alternative lives which can be considered as an escape from the mundane. Considering the continuously increasing number of people who become "residents" of these worlds and the impact of these virtual lives on their real life experiences, this study, supported with secondary data from consumer blogs in these alternative worlds, aims to discuss the interplay between the real and the virtual. Taking the issue from a relatively understudied perspective, this paper, conceptually and rather philosophically, investigates the deeper motivations of escapism and the search for meaning in life. To shed light to these inquiries, a research was conducted in consumer blogs and forums of two virtual worlds selected according to the number of subscribers: Second Life and World of Warcraft. The data was collected from two blogs and two discussion forums in which users of these virtual worlds discuss their experiences about various topics, including conversations on what these virtual worlds mean to them and how they affect their real lives. The findings reveal that even though these virtual worlds may provide its users with a feeling of having an alternative everyday life and temporarily satisfy the escapist motivations, escaping the heavily structured everyday life may not be achieved as the real everyday life
\end{abstract}

\footnotetext{
${ }^{4}$ İstanbul Kemerburgaz Üniversitesi, Yrd. Doç.Dr., dicle.yurdakul@kemerburgaz.edu.tr.

${ }^{5}$ İzmir Ekonomi Üniversitesi, Doç. Dr., deniz.atik@ieu.edu.tr.
} 
spreads to the virtual world with its institutions, including the marketing institution. For some users, the virtual worlds can be a temporary separation from dominant structures, while for others; they can be an extension of the real life as long as it continues to deliver a positive subjectivity. From a postmodern perspective, the findings also reveal that consumers do not have to choose but experience all, without necessarily rejecting or committing to one choice.

Keywords: Internet, Virtual World, Online Games, Consumer Behavior

JEL Code: M31 


\title{
GÜNDELIK HAYATTA ANLAM ARAYIŞI: SANAL, GERÇEĞIN ÜZERINDE
}

\section{EGEMENLIK KURABILIR MI?}

\begin{abstract}
ÖZET
Hızla gelişen internet teknolojileri sayesinde günümüz toplumunun insanları aynı anda birçok farklı yaşam biçimini yaşama özgürlüğüne sahiptir. Dünyanın dört bir yanında milyonlarca kişi, Second Life ve World of Warcraft gibi, insanlara kendi yaratıcıları olma imkânı tanıyan sanal dünyaların bir parçası haline gelmiştir. Bu sanal dünyalar, bireylere kendilerini ve hayatlarını yaratma özgürlüğünü sağlamakla kalmamakta, aynı zamanda insanlara gündelik olandan kaçış olarak düşünülebilecek alternatif bir hayat sahibi olma fırsatı da sunmaktadır. Bu dünyaların "sakini" olan insanların sayısındaki artış ve bu sanal hayatların gerçek hayat deneyimleri üzerindeki etkisini göz önünde bulundurarak, alternatif dünyalardaki kullanıcı bloglarından gelen ikincil verilerle desteklenen bu çalışma, gerçek ve sanal arasındaki etkileşimi tartışmayı amaçlamaktadır. Bu makale, konuyu nispeten az çalışımış bir perspektiften ele alarak, kavramsal ve felsefi olarak, kaçma eğiliminin daha derin motivasyonlarını ve hayatta anlam arayışını araştırmaktadır. Bu sorulara ışık tutmak için üye sayısına göre seçilen iki sanal dünyanın - Second Life ve World of Warcraft - kullanıcı bloglarında ve forumlarında bir araştırma yapılmıştır. Veriler, bu sanal dünyaların kendileri için ne anlama geldiği ve gerçek yaşamlarını nasıl etkilediği gibi sohbetleri de içeren, kullanıcıların çeşitli konulardaki deneyimlerini tartıştığı iki blog ve iki tartışma forumundan toplanmıştır. Elde edilen bulgular, bu sanal dünyaların, kullanıcılarına alternatif bir gündelik hayata sahip olma ve kaçış motivasyonlarını geçici olarak tatmin etme hissi sunabilmelerine rağmen, yoğun olarak yapılandırılmış olan gündelik hayattan kaçışın gerçek hayatın pazarlama kurumu da dahil olmak üzere kurumları ile birlikte sanal dünyaya da yayılmış olması nedeni ile başarılamayacağını ortaya koymaktadır. Bazı kullanıcılar için, sanal dünyalar egemen yapılardan geçici bir ayrım olabilirken bazıları için; olumlu bir öznellik sunmaya devam ettikçe, gerçek hayatın bir uzantısı olabilirler. Postmodern bir perspektiften, elde edilen bulgular, tüketicilerin bir seçeneği seçmeden ya da reddetmeden, seçim yapmak zorunda olmaksızın tüm olasılıkları deneyimleyebileceklerini de göstermektedir.
\end{abstract}

Anahtar Kelimeler: İnternet, Sanal dünya, Çevrimiçi oyunlar, Tüketici davranışı

Jel Kodu: M31 


\section{Introduction}

With the growth of Internet usage and consumption of the virtual worlds, people of the contemporary society have the freedom to experience alternative lives in which they have the power to be their own creators. Millions of people around the world have become part of the virtual worlds such as Second Life (more than 47 million users as of 2016) ${ }^{6}$ and World of Warcraft (10 million users as of 2015) ${ }^{7}$. These alternative lives might serve in the interests of the creators of these worlds, the marketers who use these mediums to communicate their messages, and the end users who immerse into this potentially more attractive world where they can experience not "given" but "self-created" bodies and lives. In literature, the motivations of creating alternative lives in these virtual worlds have been investigated mostly with a perspective of escapism in relation to the problems and difficulties of the real world (Evans, 2001; Warmelink et al., 2009). However, it may be interesting to investigate if the virtual worlds really provide what people are looking for. There is a possibility that, through time, people may find themselves entrapped also in these worlds with similar problems and difficulties they previously escaped from, specifically due to the dynamics of institutionalization that spread into the virtual domain. The question is: what is it that they are really escaping from or to. Considering the importance of the topic from a consumer research perspective, this conceptual paper, supported with secondary data from consumer blogs in these alternative worlds, aims to discuss the interplay between the real and the virtual, the deeper motivations of escapism and the search for meaning in life.

\section{a. Conceptual Background}

\section{The virtual world}

Kozinets and Kedzior (2009: 4) describes virtual worlds as "persistent, three-dimensional, networked computer represented spaces consisting of digital code and represented to people through a human-computer interface, most usually a keyboard for human input and a screen for computer output." For the purpose of this research, we define the virtual worlds as the user-created life spheres formed through computer systems where a simulation of an alternative "reality" is experienced by its users. Today, through these virtual worlds, we are speaking of human bodies and lives unbounded not only physically but also mentally and

\footnotetext{
${ }^{6}$ https://danielvoyager.wordpress.com/2016/09/07/second-life-statistics-september-2016-update/ accessed on 09.05.2017

${ }^{7}$ https://www.statista.com/statistics/276601/number-of-world-of-warcraft-subscribers-by-quarter/ accessed on 09.05.2017
} 
fictionally, having the freedom to choose from endless options to create a new identity, a new life and a new body form (Gupta and Richters, 2008).

Venkatesh et al. (1998) argue that the virtual world is an "as if" environment just like a simulator, which provides us with the opportunity to have a real-life experience without bearing the cost of our mistakes. On one hand, one could expect that this representation of the real-life cannot be a perfect substitute of it as the technology to represent it is not perfectly existent (without the senses of touch, smell, and taste for the time being); thus, it may be less valued compared to a real-life experience. On the other hand, one could also argue that, despite the limitations of the current technologies, the simulation may become superior to the real with its endless opportunities to make people feel like they have all the control and power to reach the unattainable.

Creating a new world to live in and an alternative life where one may have more pleasant experiences is a double edged sword as the effects of this virtual life may have negative consequences such as procrastination, dissatisfaction with the real life, and alienation from society. Yet, before taking a stance on the question of whether virtual life is posing a threat to real life, an essential question which needs to be answered is: what are the motivations behind creating an alternative life which may be more meaningful for its users?

\section{b. Escapism}

One of the fundamental motivations behind the consumption of the virtual spheres is largely argued in literature to be escapism (Yee, 2006; Warmelink et al., 2009; Calleja, 2010). An important contribution in consumer research comes from Hirschman (1983) who argues that the motive behind consumers' hedonic activities is to escape from their everyday lives and the reality. Modern structures of life such as going to work every day at a certain hour, taking children to school, shopping for necessities, or paying the bills may create a burden on people (Atik and Vicdan, 2012). Transformations in modern culture suggest that consumers start moving away from searching the best order of life and increasingly engage in the creation of meaningful life experiences (Firat and Dholakia, 2006). Virtual worlds, thus, may serve as a new consumption venue through which consumers may find new meanings and alternative possibilities for organizing their lives (Fırat and Dholakia, 1998).

According to Warmelink et al. (2009), in order to reveal escapism, at least two comparable contexts are needed, one of which, as we focus here, is the daily life with mundane activities and the other is the context that people create through activities to escape it, with causebased and effect-based motivations. Cause-based motivations are often related to motivations which are aimed at taking a break from the mundane activities and relieving the stress. According to Katz and Foulkes (1962), alienation and meaninglessness are the main 
dynamics which produce the desire to escape. The meaninglessness of the real life may direct individuals to search for new ways of living and escaping from their current contexts. Escaping from the meaninglessness of the everyday life, and searching for alternative contexts to find meaning can be a reason for immersing into virtual worlds. In fact, escapism requires becoming absorbed by the context in order to ensure a full psychological immersion (Mathwick and Rigdon,2004; Addis and Holbrook, 2010).

On the other hand, effect-based motivations may be pleasure seeking and daydreaming, which is mostly about creativity, imagination and enjoying an alternative reality. Warmelink et al. (2009) also argues that everybody can be considered as an escapist as all minor departures from the real life can be an escape, including drinking a cup of coffee or surfing on the internet. In the case of escapism considering the virtual life, motivations could be both cause-based, as escaping from the daily routines and problems, and effect-based as having the joy of creating an alternative life.

In literature, the word escape has been used both with positive and negative connotations, but the virtual world and game research has often focused on the negative discourse, which is mostly about the consequences of breaking the mundane, procrastination and addiction (Evans, 2001). In case of procrastination, addiction, denying the real life problems, avoiding the mundane, loss of control or devoting all the time to fantasy, escapism may eventually become an unhealthy activity (Warmelink et al., 2009).

On the other hand, with a positive connotation, escapism may be evaluated as a way to take our minds off of things, daily activities and problems and may help people, providing a sense of relief and entertainment (Evans, 2001; Yee, 2006; Warmelink et al., 2009). Hirschman (1983) argues that individuals may engage in escapist activities in order to cope better with unhappy realities or events, finding and/or creating a place where there is a more desirable state of being compared to unpleasant experiences of real-life. Therefore, these escapist activities may be serving as "anxiety reduction mechanisms" (Hirschman, 1983:64). The critical questions we would like to investigate here is: can one truly escape? Do these virtual realities provide the relief and the meaning of life one is looking for? Can it be forever or temporarily? Since the search for meaning is an essential reason for escaping from the real life (Evans, 2001), we need to look deeper in the conceptualizations of meaning and everyday life to answer these questions.

\section{c. An Existentialist Conceptualization of the Meaning of Life}

"The struggle itself toward the heights is enough to fill a man's heart. One must imagine Sisyphus happy (Camus, 1955:78)." 
The discussions about the meaning of life date back to the ancient times with Socrates's search for a rational understanding of the human beings' condition in the world. In addition to the attempts to find a rational explanation to the problem of having a meaningful life, an important stream in the existential sociology literature discusses that the human beings are not merely rational, but have strong elements of emotionality and irrationality, and they often act on the basis of their feelings or moods (Adler et al., 1987). Therefore, to have a better understanding of the struggle of people to find meaning in life, emotional and irrational aspects should be taken into consideration rather than trying to find reasonable explanations. In Albert Camus' terms, "absurd" arises out of this failure of the reason to explain the world, and particularly out of our attempts to make sense of a world which is senseless.

In "The Myth of Sisyphus" (1955), Camus joins the discussions about the meaning of life and makes an attempt to answer the most important philosophical problem, which is the suicide. It is a search for finding meaning in life; however, an attempt at finding meaning in life through "reason" causes an absurdity. Absurd is hidden in the gap between the dreams of a good life and the reality, and the divorce between wo/man and her/his life. It emerges from our attempts to make sense of life through reason and the unreasonableness of the world. According to Camus; "This world in itself is not reasonable, that is all that can be said. But what is absurd is the confrontation of this irrational and the wild longing for clarity whose call echoes in the human heart (Camus 1955:15)."

According to Camus (1955), absurd is a tension between the desire for a good, beautiful life and the existential condition of the human being on this planet. So what should the human being do to find meaning and happiness in life, given her/his absurd condition? Camus argues that nihilism or suicide is not the solution to this existential problem as he states that "The absurd dies only when we turn away from it (1955:36)." The things that give life its meaning, the things that are the answers to the question of how to turn away from absurdity are "consciousness and revolt". He argues that, "Revolt gives life its value. Spread out over the whole length of a life, it restores its majesty to that life... Metaphysical revolt extends awareness to the whole of experience (1955:36)."

He explains the consciousness and revolt through the story of the Sisyphus:

"At the very end of his long effort measured by skyless space and time without depth, the purpose is achieved. Then Sisyphus watches the stone rush down in a few moments toward that lower world whence he will have to push it up again toward the summit. He goes back down to the plain. It is during that return, that pause, that Sisyphus interests me. That hour like a breathing-space which returns as surely as his suffering, that is the hour of consciousness. At each of these moments when he leaves the heights and gradually sinks 
toward the lairs of the gods, he is superior to his fate. He is stronger than his rock (Camus, 1955: 36)."

According to Camus, Sisyphus is the proletarian of the gods. He is not different from any of us, any workman doing the same tasks each and every day, and trying to find meaning in life. Camus argues that, it is the consciousness of our condition, of our struggle in our everyday lives which is the first step for the individual revolution and victory. In order to transform our lives and the society, consciousness and metaphysical revolt should be the guiding light. Then, why can't we still find meaning in everyday life as it is suggested by Camus? How conscious are we about our condition? Why have we failed in turning away from absurdity? Are we trying to find reasonable explanations, disregarding our emotions and irrationalities? Or, is it the way "the everyday life" is constructed in the modern society? What could be the role of modern institutions in this construction?

\section{d. The Construction of Everyday Life}

To have a better understanding of these inquiries, we should look in-depth to the concept of everyday life and how it is constructed. Through an existentialist point of view, in a similar vein with Camus, Lefebvre (1992) defines the everyday life by lived experience. The reality cannot be defined only through reason, and the everyday experience is the key to develop a thorough understanding on the condition of the human. He argues that human freedom cannot be experienced within the dominating political and economic spheres of life. Consequently, one can be free only in the domain which is outside the institutional frames. He calls this domain "the everyday life". This sphere is the one which can be considered as disorganized, informal and chaotic, which means that this domain is not controlled by the economic and political structures and institutions of the modern society. According to Lefebvre's definition; "Everyday life, in a sense residual and is defined by what is left over after all distinct, superior, specialized, structured activities have been singled out... and it is in everyday life that the sum total of relations which make the human - and every human being - a whole takes its shape and its form (1992: 97)."

However, Lefebvre further claims that the everyday life has been constituted in such a way that, rather than being the realm of freedom and meaning, it has become a province of organizations, a time for self-regulation through an organized structure of production and consumption. Thus, institutions play 
a great role in the construction of the everyday life. This degraded everyday life from being the domain of freedom and meaning, to being the domain of institutions, losing its essence. Here, we are using the concept of institution in its sociological sense: "An institution is not simply a set of practices undertaken by a group of people-say politicians in the case of the nation-state and marketers for marketing-but a way of organizing a sphere of life constructed by and for members of society (Atik and Firat, 2012: 836.)" Our daily lives, which may have lost its essence for many of us, are institutionalized in every sense. We are dieting and exercising for the thin ideal that the advertised messages impose; we are using the day and night creams to look younger; we are dinning where it is most popular and driving luxury cars for social visibility; we are watching the movies and the soap operas that companies propose to us; we are believing in the often sided news of the media; we are entertaining ourselves in shopping malls, and more. Thus, we are endlessly living in institutionally constructed realities, losing our own essence and meaning. We often seem to surrender to this artificially constructed everyday life without reaching the consciousness that Albert Camus suggests, nor revolting to it. As suggested by Poster (2002), the everyday life can be the refuge of meaning only through a transformation from being the domain of passivity and consumption to being the domain of freedom and resistance.

To sum up, those of us who fail to find meaning in everyday life may look for an escape in various forms among which virtual life is an alternative as the context of this study. This new life can be the domain of freedom and resistance against the political, social and economic institutions, dominating the real everyday life experiences. In this way, individuals can escape from the meaninglessness of the real life and live in a more meaningful, self-created domain. However, our inquiries look further into: How long this joyful experience may last? Does the virtual world provide what one is looking for? What is the degree of institutionalization in the virtual world? Is the meaning lost after a while in these new alternative life spheres as well? What happens then?

To develop a deeper understanding of our inquiries, we first tried to explore the reasons why people are escaping from their real everyday lives and their expectations from their second lives, supported with data from consumer blogs in these virtual worlds.

\section{Methodology}

Our research aims to take a closer look at the experiences of the users (members) of these virtual worlds to have a deeper understanding on the interplay between the virtual and the real. A qualitative approach was adopted to understand the meaning creation process, the role of escapist motivations in this process and how long the alternative life spheres can provide the user with meaning under the effects of the institutionalization of these domains. 
We conducted a research in consumer blogs and forums of two virtual worlds selected according to the number of subscribers: Second Life and World of Warcraft (47 million and 10 million respectively). The data was collected through two blogs and two discussion forums in which users of these virtual worlds discuss their experiences about various topics ranging from gaming tools and techniques to conversations about what these virtual worlds mean to them and how they affect their real lives. Due to the sizable data available in these forums, we limited the period to one year (2014-2015) and investigated the textual data in the relevant discussion topics that took place during this period.

All discussion topics in these forums for the given period were investigated one by one to identify the relevant topics. A qualitative approach was adopted in the data analysis, as the research questions require a humanistic approach. The posts in each discussion topic were included in the data, carefully examined by the researchers and coded initially to reach the basic categories. Nvivo 8 software was used to ensure the systematic coding of the data, especially in the first and second stages of the iterative coding process. Then, through continuous comparisons, similarities and differences between the categories were discovered (axial coding process, as suggested by Carson et al., 2001). Finally, the main themes were derived which are presented as the main findings of this research in the following section.

\section{Findings}

\section{a. The Charm of the Virtual Worlds}

Among the reasons why people wish to escape from their real lives are the burden, chaos, and boredom of their everyday routines. Then, the self-created virtual sphere becomes a place to cheer up:

... Because I am not happy with my real life. If I had an exciting job, a happy family life, real good friends and no health problems, also, if I did not live in a huge city, noisy, crowdy, dirty and aggressive environment, I would maybe not be in SL (Second Life). I said MAYBE, because even if my life was fulfilled with happiness, I might just be in this virtual world for the creative and dream opportunities $S L$ has to offer. But I would not spend so much time inworld, tho.

You can escape from or you can escape to. It's one of those "glass half full or empty" things. Most of the time, I am escaping to $S L$ to do creative things that I can only do in the virtual world. Some days, though, SL's just a good place to hide and regroup -- an escape from the chaos and idiocy of $R L$ (real life). (Rolig Loon)

This new self-created context can be used as an escape from the bitter reality and become an attractive medium for people whose real lives are less than the ideal life in their minds 
(Solomon and Wood, 2009). Besides these cause-based motivations, effect-based motivations could also be at work, having the joy of doing creative things (Warmelink et al., 2009):

That's why it's called "Second Life"! You can be whatever you like in here, create totally different persona than you are in RL! Be whatever you like, from plywood box that just sites there and looks inert or super speedy alien that buzes around, you can be male in $R L$ and female in SL, or other way around, you can be 80yo rl and RP as 12yo kid in SL! Choice is yours to act like something/someone you are not in $R L$, personality/look/gender/species or be same as you in RL!!! SL is not a game, games have a goal, fixed characters with limited development ability, levels that are premade by game makers etc. SL does not have that, it is $3 d$ world with community of various residents, it is $99 \%$ resident made content and endless possibility of your second persona development, you choose what you will be and how will you act!! (Min Barzane)

After logging into these virtual worlds, the first action of the user is to create an avatar which is the representation of the user's body in this new world, and this-re-embodiment process has no limits as the users have the opportunity to select and assemble body parts from countless alternatives (Kozinets and Kedzior, 2009). In a sense, the user is redefining her/his social existence. The endless opportunities for creating her/his own body allows an individual to experiment many different body parts, bodies, sexes and identities. This postmodern representation of the body is, in a sense, a celebration of freedom from restrictions (Kolko, 1999). Although, we have attempts to alter our physical appearance through a variety of tools such as cosmetics or plastic surgery in real-life, a considerable effort needs to be devoted to realize this change, and the consequences of these attempts are often not reversible. However, in the virtual world, people are freed from the paradox of choice as there is no cost of making a wrong decision. This also supports the suggestions of Shankar and Fitchett (2002:512) that consumers will reject the discourse of having and embrace a "marketing of being": goods and services will be valued by consumers on the basis of their ability to facilitate a positive sense of being and identification," which the virtual worlds very much provide. Then, the question becomes: how real can these new forms of being be?

\section{b. Interplay of the two Worlds: How Real Can the Virtual Become?}

Following the above inquiry, we explore here how much a substitute a virtual life experience can be for the real. For some, it can be as real as the real life itself or even better:

Actually, I consider Second Life a Reality. It is just that it is taking place in a Virtual World. I am not interacting with a computer. I am interacting with other people, Residents of Second Life. It does afford me the ability to explore other life styles in ways 
that I can't in the real world in a safe environment. Should I discover I don't like something I can always click the red $X$ at the top of my screen. There were sides to me that I learned how to express in SL that might have been much more difficult to do in the real world. I feel more unified as a person. (Perrie Juran)

While this is definitely not a copy of my RL physique, my avatar is "me" in a very deeplyrooted sense. Sometimes I think, that it is more "me" as an expression of my inner self, than my body in RL. (Deirdre Boyer)

As Venkatesh, Meamber and Firat (1998) argues, the virtual world is an "as if" environment just like a simulator. Sometimes, this simulation becomes superior to the real with its endless opportunities to make people feel like they have all the control and power to reach the unattainable:

As my avatar flies around the fantastic world of Faery Crossing, I wonder how many people here would rather choose Second Life over their real life. Who wouldn't prefer the fun and controlled environment of a game over our often haphazard lives in reality? In reality, my body is limited, my appearance more or less fixed, my position in society dictated by my background and education. In virtual worlds, I am able to recreate myself to my desire. I can play as a more confident, better looking, and braver version of myself. I can work dream jobs here that I may not be qualified for in real life, make friends with strangers who I would not have approached before, purchase luxury items that were once out of my reach. There is something addictively satisfying about these possibilities. Playing in the virtual world, we regain a sense of control over our lives. These possibilities make the virtual world very seductive, even genuinely addictive, to some gamers. If Second Life offers you a dream world, why would you ever leave? (Minty)

For some, it could even become a life saver:

A dear friend of mine used to say (and have in her profile), "SL is my "do over" - how I would like to live my life if I could do it all again. "SecondLife" to her didn't mean "not real life," it meant "a second chance." We had been friends for 15 years and she had been very ill for most of that time. In the last few years of her life, SL *was* her "life" as she was bedridden; it was her sole outlet for socializing, being the businesswoman she had been in RL, etc. Unfortunately she died last Nov. (Reality check)

Despite the previously discussed potential downsides (such as procrastination and addiction) of spending too much time in the virtual, we also observe that these virtual experiences can have positive effects on the real life to a certain degree and for some people:

I'll confess that I have enjoyed a personal transformation due to the confidence I've gained through my experiences in Second Life. When I began playing SL, I was more than twenty 
pounds heavier, with shorter hair, and had suffered a minor crisis of confidence caused by a company re-org that orbited my career into a professional planetary tailspin. Yet now, over a year and a half later, I've slimmed down, grown my hair to match the length of my avatar and landed my dream job. And I'm not alone here; I've heard countless tales of friends who likewise have been motivated to match the model of their online personas by exercising and exhibiting increased confidence in their personal and professional lives. On the flip side, I've also suffered from melancholy and minor depression when I've experienced loss, pain, or loneliness within Second Life. (Candygarden)

In a sense, executing the dreams and fantasies of the real world in a second (virtual) life, witnessing the fantasy to be attainable, one can gather the strength to fight back in the real world to achieve that ideal being; in the above case, ideal physical being. We can say that for some, the achievements and satisfactions of the second life can increase the joy of life in general and provide enthusiasm for the real.

Another interesting point here is that the participant of the second life brings her real life fantasies to virtual and these fantasies, which is related to ideal physical beauty here, are often endorsed by modern institutions such as advertising in fashion or cosmetics, which promote instructions for weight management and physical appearances, reinforcing these as essential for women's self-esteem and social success (e.g. Bordo, 1993; Wolf, 1991). Accordingly, women are under the influence of these images, trying to fit in, still in their second lives. "Since the media often constructs simulated identities, based around product and brand ensembles, which are portrayed as successful, healthy, secure, happy, youthful, and sexy, consumption sometimes becomes a source of false promises (Murray, 2002: 436)." Coming back to Lefebvre's (1992) argument; if one can be free only in the domain which is outside the institutional frames; then, an interesting question arises: How long this joyful experience may last in the virtual? Can one truly escape from or to?

I am still not sure if SL influence is positive or negative on my RL. What I know is that FOR SURE SL affects my RL in many ways. I must confess I have two avatars in SL. The first avatar I created is beautiful, but after a while I find out that her life was becoming so much as my RL. A stable relationship, good friends, a family, a house... and I suddenly realized I was not happy with that, I was replicating myself... and I found out that I wanted to be different from my RL. That's why I created Candy. She is different from me, beautiful but different. I am trying to find out other aspects of my personality through her. So basically, I got a second life to "escape" from my RL and now I have a third life to "escape" from my second life. Should I need a psychologist?? Lol (Candycandy) 
One can escape temporarily; the virtual world may provide temporary satisfaction, but the search never ends. Besides the entrapping role of institutional frameworks, Fiske (1989) argues from a different perspective that in Western societies people see time as linear, forward moving, productive of change, and this brings the social sense of progress, improvement and development. This modern ideology of progress could be the engine for this restless search and longing for an imaginary or an altered state of existing in life. Consumption objects or in this context virtual lives become "a bridge to displaced meaning and an idealized version of life as it should be lived (McCracken, 1988: 110)."

\section{c. Dominating Role of Institutions in the Virtual}

Even though we know that the institutions of the real life such as the market system have already started to diffuse to the alternative lives through the emergence of real life brands and corporations (e.g. IBM headquarters), the degree of institutionalization seems to increase day by day; for instance, having stores powered by Amazon.com or fashion designers, making millions of "real" dollars through selling their creations. For some, all this institutionalization makes Second Life a less attractive world, losing its essence just like the

"real everyday life":

I too struggle with body image in TAW (the actual world, as I like to call it), and SL. My original avatar, used for the past two years, was an emaciated, elongated version of my too thin teenage self. I have recently created an avatar shape that is more appropriately proportioned for an actual, normal human figure. As a result, I look too short, and not busty enough, or long-legged enough, to fit in with the SL "ideal" woman. Why must this feeling of needing to be perfect follow us even into virtual worlds? What has our society done to us, most especially to women, it seems, when such a high premium is placed on physical perfection? (Dared)

As it is revealed above, the ideal body image which is a product of the contemporary market system is transferred to Second Life as well as many Second Life users claim that an attractive avatar is the key to building social and romantic relationships. The ideal beauty image and the desire for physical perfection follows women to the virtual world, making them try to adhere to the norms of the contemporary society in terms of how to look and act. These norms, in fact, limit the choice to construct one's avatar as s/he wish, as the desire for social conformity and likability may dominate over the desire for the sense of freedom.

Surprisingly, this desire for creating a "socially acceptable and likable" body goes so far that we witness the emergence of companies who focus on changing one's real body to look alike her/his avatar through preparing a personal reshaping plan with the idea that the avatar may reflect the ideal beauty/self in one's mind. This shows us the increase in the level of interaction between the real and the virtual, which eventually leads to the increase in the 
level of social and institutional structures reshaping this alternative life and turning it into an extension of the real life.

One day I went to rent a place as my sleazy-dressed av, and they questioned my ability to pay, and went into a long-winded diatribe of what would happen if I didn't, and perhaps I should look for a "more economical" home, and it was clear they didn't want me there....so I logged back in as my upscale av in evening gown....and they practically bent over backwards, and offered a week's free rent.(Fury)

Even though Second Life is created as an alternative everyday life, and used by some of its users with escapist motivations such as staying away from the burdens and problems of the real everyday life, it can also be argued that a real escape from the structured, constituted everyday life may not be achieved as the real everyday life spreads to the virtual world. In this case, the upscale looks of the user's avatar provides her/him likability and respect, which means that the materialist motivations in social interactions and communications are carried to the virtual sphere too. If one needs to buy a gown with lindens $s /$ he buys with her/his "real money" to be treated properly, it can be argued that this alternative life is also becoming just like the "real" everyday life which s/he wanted to escape from. In addition, it can be accepted as strong evidence to the existence of a market system there, in every sense.

However, contrary to real life, it can be argued that people still have the choice to stay away from the market system or protect themselves from its side-effects through not participating in the system. Yet, in that case, the freedom of creating one's life totally according to her/his desires will be constrained by the very well-known rules and structures of the everyday life, which means that we're no more speaking of a domain which gives people the opportunity for freedom and escape.

\section{Conclusion}

"A good traveler has no fixed plans and is not intent upon arriving. - Lao-Tzu"

We would like to end our discussion by coming back to Camus' argument that it is the consciousness of our condition, of our struggle in our everyday lives which is the first step for the individual revolution and victory. As revealed by the findings of this study and the previous studies in the domain of consumer research, it is not possible, in any meaningful sense, to escape market relationships; rather people can inhabit liberated spaces and resistance and empowerment may take place within the logic of the market (Kozinets, 2002; Peñaloza and Price, 1993). For some, these spaces can be a temporary separation from dominant structures, which the virtual worlds partly provide. Others may fully commit to a consumption lifestyle so long as it continues to deliver a positive subjectivity, i.e. people 'like' 
being consumers (or at least they continue to think they do) - like the handicapped girl who died.

Postmodern perspectives also contribute here as consumers start moving away from searching the best order of life and increasingly take part in experiencing and experimenting with alternative life modes (Firat and Dholakia, 2006). This means that consumers do not have to choose if they do not like to but experience all, without necessarily rejecting or committing to one choice (Atik and Vicdan, 2012). We would like to come back to the above quote: "A good traveler has no fixed plans and is not intent upon arriving. - Lao-Tzu" There is not a perfect world where we can come into existence, but on the pathway to it, during our struggle in our everyday lives where the meaning lies if one can be conscious about it (Camus, 1955).

To summarize, with the hope to stimulate further discussion and research, this paper conceptually and rather philosophically, tried to investigate the deeper motivations behind escapism in the search for meaning within the context of the virtual worlds. As a future research direction, we suggest a systematic empirical research with the consumers of these worlds to show the different degrees of escapism and broader effects of real/virtual interactions. 


\section{REFERENCES}

Addis, Michela and Morris B. Holbrook (2010). "Consumers' Identification and Beyond: Attraction, Reverence, and Escapism in the Evaluation of Films"; Psychology \& Marketing, 27(9) , p. 821-845.

Adler, Patricia A., Peter Adler and Andrea Fontana (1987). "Everyday Life Sociology"; Annual Review of Sociology, 13(1), p. 217-235.

Atik, Deniz and A. Fuat Firat (2012). "Fashion Creation and Diffusion: The Institution of Marketing"; Journal of Marketing Management, 29(7-8), p. 836-860.

Atik, Deniz and Handan Vicdan (2012). "The Interplay of Culture(s) of Freedom in the Bazaars of Italy and Turkey"; Journal of International Consumer Marketing, 24(1-2), p. 100-118.

Bordo, Susan (1993). Unbearable Weight: Feminism, Western Culture, and the Body, Berkeley: University of California Press.

Calleja, Gordon (2010). "Digital Games and Escapism"; Games and Culture, 5(4) , p. 335-353.

Camus, Albert (1955). The Myth of Sisyphus and Other Essays, New York: Vintage Books.

Carson, David, Audrey Gilmore, Chad Perry and Kjell Gronhaug (2001). "In-depth interviewing", In Qualitative Marketing Research (ed. by D. Carson, A. Gilmore, C. Perry \& K. Gronhaug), p. 73-91,London: Sage.

Evans, Andrew (2001). This Virtual Life: Escapism and Simulation in Our Media World, London: Fusion Press.

Firat, A.Fuat and Nikhilesh Dholakia (1998). Consuming People: From Political Economy to Theaters of Consumption, London: Routledge.

Firat, A.Fuat and Nikhilesh Dholakia (2006). "Theoretical and Philosophical Implications of Postmodern Debates: Some Challenges to Modern Marketing"; Marketing Theory, 6(2), p. 123-162.

Fiske, Susan (1989). "Examining The Role of Intent: Toward Understanding its Role in Stereotyping and Prejudice", In J. Uleman \& J. Bargh (Eds.), Unintended Thought: The Limits of Awareness, Intention, and Control, p. 253-283, New York: Guilford Press.

Gupta, Jyotsna Agnihotri and Annemiek Richters (2008). "Embodied Subjects and Fragmented Objects: Women's Bodies, Assisted Reproduction Technologies and the Right to Self-Determination"; Journal of Bioethical Inquiry, 5(4), p. 239-249. 
Hirschman, Elizabeth C. (1983). "Predictors of Self-Projection, Fantasy Fulfillment and Escapism"; Journal of Social Psychology, 120(1), p. 63-76.

Katz, Elihu and David Foulkes (1962). "On the Use of the Mass Media as Escape: Clarification of a Concept," Public Opinion Quarterly, 26(3), p. 377-388.

Kolko, Beth E. (1999). "Representing Bodies in Virtual Space: The Rhetoric of Avatar Design"; The Information Society, 15(3), p. 177-186.

Kozinets, Robert V. (2002). "Can Consumers Escape the Market? Emancipatory Illuminations from Burning Man"; Journal of Consumer Research, 29(1), p. 20-38.

Kozinets, Robert V. and Richard Kedzior (2009). "I, Avatar: Auto-Netnographic Research" in N.T. Wood and M.R. Solomon (Eds.), Virtual Social Identity and Consumer Behavior, p. 3-19, New York: ME Sharpe.

Lefebvre, Henri (1992). The Critique of Everyday Life, Vol. I. London: Verso.

Mathwick, Charla and Edward Rigdon (2004). "Play, Flow, and the Online Search Experience"; Journal of Consumer Research, 31(2), p. 324-332.

McCracken, Grant (1988). Culture and Consumption. Bloomington: Indiana University Press.

Murray, Jeff B. (2002). "The Politics of Consumption: A Re-Inquiry on Thompson and Haytko's (1997) "Speaking of Fashion"; Journal of Consumer Research, 29(3), p. 427-440.

Peñaloza, Lisa and Linda Price (1993). "Consumer Resistance: A Conceptual Overview"; Advances in Consumer Research, 202 (11), p. 123-128.

Poster, Mark (2002). "Everyday (virtual) life"; New Literary History, 33(4), p. 743-760.

Shankar, Avi and James A. Fitchett (2002). "Having, Being and Consumption"; Journal of Marketing Management, 18(5-6),p. 501-516.

Solomon, Michael and Natalie T.Wood (2009). "Introduction: Virtual Social Identity Welcome to the Metavers" in N.T. Wood and M.R. Solomon (Eds.), Society for Consumer Psychology. New York: M.E. Sharpe.

Venkatesh, Alladi, Laurie Meamber and A. Fuat Firat (1998). "Cyberspace as the Next Marketing Frontier (?) - Questions and Issues", in S. Brown and B. Turley (Eds.), Consumer Research: Postcards from the Edge (p. 301-321). New York: Routledge. 
Warmelink, Harald, Casper Harteveld and Igor Mayer (2009). "Press Enter or Escape to Play: Deconstructing Escapism in Multiplayer Gaming"; Proceedings of DIGRA 2009, p. 1-9.

Wolf, Naomi (1991). The beauty Myth: How Images of Beauty are Used Against Women", New York: Anchor Books.

Yee, Nick (2006). "Motivations for Play in Online Games"; Journal of Cyberpsychology and Behavior, 9(6), p. 772-775. 